\title{
Från Bysans till Putin. Historier om Ryssland
}

\author{
Per-Arne Bodin
}

Skellefteå: Artos \& Norma bokförlag 2016

286 sidor. ISBN 9789172171039

Recenserad av: Ingmar Oldberg [associerad forskare, Utrikespolitiska institutet, Stockholm, ingmar.oldberg@gmail.com]

Liksom andra böcker av Per-Arne Bodin, professor emeritus i slaviska språk vid Stockholms universitet, består denna av en samling tidigare publicerade artiklar, som fördjupats, samordnats och försetts med hänvisningar. Artiklarna behandlar de mest spridda ämnen; från ortodoxa ritualer och patriarken Tichons kanonisering till dubbelörnens återkomst som statsvapen, Moskvas tunnelbana och Pussy Riot. Boken följer den ryska kulturhistoriens långa linjer från den bysantinska traditionen genom tsarväldet och sovjettiden fram till Putins styre i 2015. Den belyser samspelet dels mellan kultur och politik, dels mellan andlighet och makt. Genom att analysera kulturhistoriska teman, »kulturogem», deras förvandlingar och särskilt den ortodoxa traditionen, vill boken också bidra till förståelsen av dagens Ryssland.

Bodin bygger på ett rikt källmaterial som omfattar rysk-ortodoxa, politiska och skönlitterära källor, vidare västlig forskning och filosofi, samt svenska reseskildringar från 1600-talet och senare. Man undrar dock vem Maria Engqvist är som avtackas i förordet. Genomgående använder sig Bodin av bilder i olika former; ikoner, konst, foton, filmer och teaterföreställningar, och boken är fint illustrerad. Han drar sig inte för att bilda läsarna genom att presentera vetenskapliga svenska och ryska begrepp.

De olika kapitlen bibringar mycken kunskap och djupa insikter om Ryssland, men man vill ändå sätta några frågetecken. Det inledande kapitlet om dubbelörnen, som åter blev statsvapen 1993, analyserar redigt dess förändringar sedan tsartiden och hur vapnet behandlats i konst och litteratur i postsovjetisk tid. Dock är kanske Bodins slutsats att de imperiebekräftande konstnärerna dekonstruerar sitt budskap för att skydda det, medan de liberala dekonstruerar deras dekonstruktion eller tvärtom, lite snårig. Vid granskningen av statsvapnets sköld undrar man över vad det betyder att riddaren vänts från höger till vänster (väst-öst?).

Två fascinerande kapitel ägnas fyra ortodoxa ceremonier, nämligen åsnevandringen till åminnelse av Jesu intåg i Jerusalem på palmsöndagen, ugnsspelet om ynglingarna som enligt Daniels bok i Gamla testamentet brändes i en ugn, Jesu fotatvagning av lärjungarna vid den sista måltiden, samt badandet i isvakar på epifaniadagen till minne av Jesu dop i Jordanfloden. Bodin visar hur skildringarna 
och förändringarna av dessa ceremonier genom tiderna återspeglar maktförhållandena mellan kyrkan och den världsliga makten för att under senare år sekulariseras och medialiseras.

Kapitlet om representationer av Ivan den förskräcklige utgår från Ilja Repins berömda tavla av tsarens mord på sin son och granskar hur denna tolkats i olika tider, bland annat av Selma Lagerlöf 1912. Hon såg Ivans hemska ögon som ett varsel om en blodig revolution. Perspektivet vidgas sedan till synen på tsaren genom tiderna, från kritik till nutidens hyllningar. Efter bokens publicering har en staty rests över tsaren i Orjol, vilket förorsakat ett ramaskri utomlands.

Bokens mest avancerade kapitel, som antagligen presenterats på någon semiotisk konferens, handlar om ikoner som teologi. Det börjar med en presentation av striden mellan ikonoklaster och ikonoduler i Bysans på 700-800-talen om huruvida ikoner kunde förmedla ett religiöst budskap. Det fortsätter med den ryske religionsfilosofen Pavel Florenskij i början av 1900-talet och semiotikerna på 1970-80-talen, vilka sedan jämförs med tre franska postmodernistiska filosofer. Bodin påvisar intressanta skillnader mellan Florenskij och fransmännen ifråga om förhållandet mellan ikonen, konstnären, betraktaren och en närvarande, icke existerande eller dold Gud.

Kapitlet om Moskvas tunnelbana beskriver denna som Stalins viktigaste skrytbygge, som blev mönsterbildande och ett försök att bygga ett slags världsliga katedraler under jord. Det klargör hur tunnelbanan präglats av utopisk socialistisk realism och skildrats i dystopisk litteratur och till och med förekommer i dataspel. Verklighetens tunnelbana hotas av terrorattentat och fylls alltmer av kommersiell reklam.

I kapitlet om Stalins Moskvarättegångar i 1936-38, där Bodin anlägger ett kulturhistoriskt perspektiv, ses skådeprocesserna som en form av teater, som inspirerats av Stanislavskijs sökande efter autencitet och avmaskering. Han visar hur rättegångarna försvarades av kommunistiska författare och teatermän som Lionel Feuchtwanger och Bertolt Brecht som rättvisa och som en nödvändig förberedelse för kriget mot Nazityskland. Bodin menar helt riktigt att rättegångarna i själva verket försvagade krigsmakten, tystade allt kritiskt tänkande inom partiet och sådde fröet till sovjetimperiets undergång många decennier senare.

I de återstående kapitlen återvänder Bodin till kyrkan och dess förhållande till samhället. Kapitlet om Pussy Riot sätter in konstnärsgruppens framträdande i Kristi-Frälsarekatedralen, Rysslands kanske heligaste rum, 2012 och domen därefter i en rysk tradition av intellektuellas och konstnärers protester mot den politiska och kyrkliga makten, där både heliga dårar (»jurodivye») och karnevalsupptåg ingår. Bodin ser en olöslig konflikt om huruvida framträdandet var ett konstverk, men hävdar också att där fanns en stark kritik av vårt västerländska samhälle. I frågan om konstnärsprotester sedan 2000-talet finns det beröringspunkter med Lena Jonsons forskning, som Bodin gott kunde ha nämnt.

Kapitlet om kanoniseringen av patriarken Tichon (1917-1925) handlar om hur minneskulturen kring honom utvecklats från sovjetiskt förtryck till helgonförklaring 1989 och nutida hymnografi och ikonografi. Bodin tar också upp »svåra» frågor som 


\section{INGMAR OLDBERG}

Tichons inställning till kriget 1917 och lojalitetsförklaringen till sovjetmakten. Han upptäcker även en svensk länk genom skämttecknaren Albert Engström.

Det avslutande kapitlet om synen på den ryska kyrkan i stormaktstidens Sverige faller visserligen något utanför ramen genom sitt utifrån-perspektiv, men det innehåller intressanta och roande referat av svenska resenärers iakttagelser i Ryssland. Han visar att texterna inte alls är enbart negativa och karikerande som man kunde förvänta sig utan vittnar om faktakunskaper och genuint intresse av likheter med den protestantiska kyrkan.

Av allt detta drar Bodin slutsatsen att den kristna traditionen fortsätter att fungera som ett starkt kulturskapande element i Ryssland trots (eller tack vare) 70 års sovjetmakt. Numera präglas kulturen av postmodernism, sanningssökande och medialisering. Samma »kulturogem» kan användas både i populärkultur och i politik, för totalitära såväl som demokratiska syften. Detta har Bodin visat på ett övertygande och underhållande sätt. Alla som är intresserad av rysk kulturhistoria bör läsa boken. 